\title{
Application of Exhaust Gas Fuel Reforming in Diesel and Homogeneous Charge Compression Ignition (HCCI) Engines Fuelled with Biofuels
}

\author{
A. Tsolakis ${ }^{\mathrm{a}}$, A. Megaritis ${ }^{\mathrm{b}}$, D. Yap ${ }^{\mathrm{c}}$ \\ ${ }^{a}$ School of Engineering, Mechanical and Manufacturing Engineering, \\ University of Birmingham, Birmingham B15 2TT, UK. \\ ${ }^{\mathrm{b}}$ Mechanical Engineering, School of Engineering and Design \\ Brunel University, West London, Uxbridge UB8 3PH, UK \\ ${ }^{c}$ Singapore Institute of Manufacturing Technology, \\ 71 Nanyang Drive, Singapore 638075.
}

Received: 14 June 2007

\begin{abstract}
This paper documents the application of exhaust gas fuel reforming of two alternative fuels, biodiesel and bioethanol, in internal combustion engines. The exhaust gas fuel reforming process is a method of on-board production of hydrogen-rich gas by catalytic reaction of fuel and engine exhaust gas. The benefits of exhaust gas fuel reforming have been demonstrated by adding simulated reformed gas to a diesel engine fuelled by a mixture of $50 \%$ ultra low sulphur diesel (ULSD) and 50\% rapeseed methyl ester (RME) as well as to a HCCI engine fuelled by bioethanol. In the case of the biodiesel fuelled engine, a reduction of $\mathrm{NO}_{\mathrm{x}}$ emissions was achieved without considerable smoke increase. In the case of the bioethanol fuelled HCCI engine, the engine tolerance to exhaust gas recirculation (EGR) was extended and hence the typically high pressure rise rates of HCCI engines, associated with intense combustion noise, were reduced.
\end{abstract}

Keywords: Biodiesel; Bioethanol; HCCI; Fuel Reforming; Hydrogen

\footnotetext{
* Corresponding author. Tel.: +44 (0)1895 266682, Fax: +44 (0)1895 256392

Email address: thanos.megaritis@brunel.ac.uk
} 


\section{Introduction}

Research on alternative renewable fuels has become very important worldwide due to concerns about the effects of fossil fuel usage on global warming. Alternative fuels such as biodiesel and bioethanol have been proposed as engine fuels. They can be made from renewable raw material and can offer reduction of fossil fuel consumption.

Biodiesel (ester-based oxygenated fuel) is produced from renewable resources like vegetable oil or animal fat and it is biodegradable. It can be used as neat or blended with diesel in compression ignition (CI) engines and has beneficial effects on $\mathrm{CO}_{2}$ emissions. The oxygen content and the lower calorific value of biodiesel generally results in a measured loss of engine power and an increase of fuel consumption but the engine efficiency is unaffected or even improved. Regarding exhaust emissions, the use of biodiesel results in lower emissions of unburned hydrocarbons, carbon monoxide, smoke and particulate matter (PM) [1-4]. The majority of the published work indicates some increase in $\mathrm{NO}_{\mathrm{x}}$ emissions with biodiesel compared to standard diesel fuel but NOx emission results that vary widely continue to be presented and appear to depend upon engine manufacturer or engine design [5]. In general, the combustion of biodiesel in unmodified CI engines equipped with pump-line-nozzle fuel systems results in advancement of the combustion process that leads to increased $\mathrm{NO}_{\mathrm{x}}$ emissions compared to diesel fuel. This is due to differences in chemical and physical properties of the fuels [6-12]. For engines equipped with unit injector or common rail injection systems these effects are yet not so clear [5] and substantial clarifications continue to be reported in the literature, e.g. [12,13].

While biodiesel is aimed at the diesel engine market, bioethanol has been mainly used as a fuel for gasoline SI engines (although bioethanol-diesel mixtures have been shown to be viable fuels for diesel engines). Bioethanol is a pure substance $\left(\mathrm{C}_{2} \mathrm{H}_{5} \mathrm{OH}\right)$ produced from renewable raw 
material [14]. Bata et al. [15] studied different ethanol-gasoline blends in engines, and found that ethanol could reduce the $\mathrm{CO}$ and unburned hydrocarbon emissions to some degree. The reduction of $\mathrm{CO}$ emissions is apparently caused by the wide flammability range and oxygenated characteristic of ethanol. Taljaard et al. [16] have reported that the addition of oxygenates in gasoline significantly decreases the $\mathrm{CO}, \mathrm{NO}_{\mathrm{x}}$ and $\mathrm{HC}$ emissions at stoichiometric air fuel ratios.

In parallel to the interest in renewable fuels, there has also been increased interest in HCCI combustion. HCCI engines are being actively developed because they have the potential to be highly efficient and to produce low emissions. They can have efficiencies close to these of diesel engines, with low levels of emissions of $\mathrm{NO}_{\mathrm{x}}$ and particulate matter [17-19] and they have been shown to operate with a range of fuels, including bioethanol [20-23]. SI engines can be operated in HCCI mode at stoichiometric air fuel ratios using residual gas trapping [24]. This approach has the advantage of reducing additional intake heating requirements for the autoignition process to begin, thus achieving HCCI combustion at ambient intake temperatures at widely used compression ratios (CR) of about 10 [24,25].

The application of EGR in diesel engines is an effective way of $\mathrm{NO}_{\mathrm{x}}$ emissions reduction but it is associated with increased exhaust smoke and particulate emissions as well as fuel consumption. On the other hand, the addition of hydrogen to the main hydrocarbon fuel has been reported to be beneficial in terms of brake power, thermal efficiency and reduction of $\mathrm{HC}, \mathrm{CO}$, $\mathrm{CO}_{2}$ and particulates, e.g. [26,27]. The increased peak cylinder pressure and temperature occurring with hydrogen addition tend to increase $\mathrm{NO}_{\mathrm{x}}$ emissions except for lean mixtures [28]. The application of EGR to HCCI combustion has minimal benefit in terms of $\mathrm{NO}_{\mathrm{x}}$ emissions due to the already typically low $\mathrm{NO}_{\mathrm{x}}$ levels. However, by reducing the combustion rates, it can be beneficial in reducing the typically high cylinder pressure rise rates of HCCI engines associated 
with intense combustion noise. Addition of hydrogen would extend the engine tolerance to external EGR and hence it will assist in the reduction of combustion noise.

The production and storage of hydrogen for internal combustion (IC) engine applications are still challenging but the associated issues can be overcome by production of hydrogen from liquid or gaseous fuels just before use. A way of producing hydrogen 'on-board' for IC engine applications is the exhaust gas fuel reforming process. The process involves the catalytic reaction of engine exhaust gas (source of steam and oxygen at high temperature) with hydrocarbon fuel to produce hydrogen-rich gas (gas which mainly contains $\mathrm{H}_{2}, \mathrm{CO}, \mathrm{CO}_{2}$ and un-reactive hydrocarbons). The fuel is injected into a catalytic reformer fitted into the EGR system, so that the produced gas mixture is fed back to the engine as reformed EGR (REGR). Exhaust gas fuel reforming is a combination of all the basic reforming processes (i.e., oxidation, steam reforming reaction (SRR) and water gas shift reaction (WGSR)) [29,30]. In this work, simulated REGR was used in a CI engine fuelled with a ULSD-RME mixture to assess the effects of the application of fuel reforming on emissions and fuel consumption. In addition, simulated REGR was used in a bioethanol fuelled engine operating in HCCI mode. The engine tolerance to REGR was evaluated and compared with the tolerance to standard EGR.

\section{Experimental Setup and Procedure}

Diesel Engine Test Rig. The experiments with the biodiesel mixture were carried out in a Lister-Petter TR1 engine. The engine is a $773 \mathrm{~cm}^{3}$, naturally aspirated, air-cooled, singlecylinder direct injection diesel engine. The fuel injection system (unmodified as provided by the manufacturer) has a three-hole nozzle with a hole diameter of $0.25 \mathrm{~mm}$, located near the combustion chamber centre with an opening pressure of 180 bar. The engine piston is a bowl-inpiston design. An electric dynamometer with a motor and a load cell was coupled to the engine 
and used to load and motor the engine. The engine test rig has been described in detail in previous publications [26,31]. Results obtained at two different engine operating conditions are presented as representative to demonstrate the effects of simulated REGR on the $\mathrm{NO}_{\mathrm{x}}-\mathrm{smoke}$ trade-off, fuel economy, and engine performance. The two operating conditions were $1500 \mathrm{rpm}$ engine speed, 4.5 bar IMEP (indicated mean effective pressure) and $1500 \mathrm{rpm}, 6.1 \mathrm{bar}$ IMEP. Tests were carried out with two different injection timing settings. The two injection timings were 22 CAD (crank angle degree) BTDC (before top dead centre), referred to as standard injection timing, and 19 CAD BTDC, referred to as retarded injection timing. All the tests were performed with a mixture of $50 \%$ ULSD (46 mg/kg sulphur content) and 50\% RME, referred to as B50. The ULSD and RME properties are given in Table 1. The levels of REGR used were $10 \% \pm 0.6 \%$ and $20 \% \pm 0.6 \%$ expressed as volumetric percentages of the total volumetric flow rate at the engine inlet. REGR was simulated by using conventional EGR together with hydrogen addition at the engine inlet manifold. The composition of the mixture was similar to that which would be obtained at optimized reaction conditions using a mini reformer described in earlier publications [26,32]. The REGR hydrogen content was $24 \%$ vol. For the present tests with simulated REGR, the brake specific fuel consumption (BSFC) was calculated using the predicted total fuel flow that would be required in a real close coupled engine-reformer system, i.e., both engine and reformer fuel consumption. The reformer fuel flow was estimated using open loop reforming test data. For each test, it was calculated as the fuel that would be required in the reactor in order to produce the same quantity of reformed gas as the quantity of the simulated REGR used. This estimated reformer fuel flow was added to the measured engine fuel flow and thus the 'total system fuel consumption' was determined.

HCCI Engine Test Rig. The experimental work was carried out using a single cylinder engine with a Rover K series engine cylinder head. The single cylinder engine forms a quarter of 
a standard $\mathrm{K}$ series 1.8 litre having been engineered to fit the single cylinder crankshaft with custom balance shafts. The bore and stroke of the engine are $80 \mathrm{~mm}$ and $88.9 \mathrm{~mm}$, respectively. For the HCCI tests presented here the compression ratio was raised to the value of 12.5, using a racing style piston. The engine was coupled to a DC dynamometer which was used to load and motor the engine. The test rig has been described in detail in an earlier publication [33]. All the tests were conducted at $1500 \mathrm{rpm}$ with anhydrous bioethanol. The bioethanol properties are given in Table 1. The engine was run at stoichiometric air fuel ratio with residual gas trapping and without intake air heating. The engine inlet temperature was not controlled but it varied very little from $22-23{ }^{\circ} \mathrm{C}$ at standard operation without EGR/REGR to $27-28{ }^{\circ} \mathrm{C}$ when the maximum percentage of EGR was added (the inlet temperature differences between operation with the same EGR and REGR percentages were up to $2{ }^{\circ} \mathrm{C}$ ). Negative valve overlap was used to trap residual gases. The simulated REGR contained $20 \%$ vol. hydrogen, based again on data obtained with the mini reformer.

Exhaust gas analysis for both engines included measurement of $\mathrm{CO}_{2}, \mathrm{CO}$, unburned hydrocarbons, $\mathrm{O}_{2}$ and $\mathrm{NO}_{\mathrm{x}}$ emissions. Smoke was measured using an EFAW 68A Bosch smoke meter giving smoke emissions in terms of Bosch Smoke Number (BSN). The hydrogen contents of the reforming reactor product were measured by gas chromatography. Atmospheric conditions (humidity, temperature, pressure) were monitored during the tests. Table 2 shows the accuracy of the measurements and the uncertainty of the computed results of the various parameters.

\section{Results}

\subsection{Biodiesel reforming and combustion results}

Diesel engines operate lean and the water and oxygen contents of the engine exhaust gas depend mainly on the engine load. Table 3 shows the diesel engine exhaust gas composition and 
the excess air ratios $(\lambda)$ for the two engine operating conditions described earlier. As expected, the increase of the engine load resulted in the increase of $\mathrm{H}_{2} \mathrm{O}$ contained in the exhaust gas with a simultaneous reduction of $\mathrm{O}_{2}$.

The use of different engine exhaust gas temperatures and compositions due to different engine conditions requires adjustments of the reactant flows in the reforming process so that both maximum hydrogen production and process efficiency can be achieved [26,29,32,34]. The reactant ratios (oxygen to carbon atomic $(\mathrm{O} / \mathrm{C})$, oxygen to carbon molar $\left(\mathrm{O}_{2} / \mathrm{C}\right)$ and steam to carbon molar $\left.\left(\mathrm{H}_{2} \mathrm{O} / \mathrm{C}\right)\right)$ with the use of different reactant flows are shown in Table 4 . They were calculated based on the chemical formulae of ULSD $\left(\mathrm{C}_{15.08} \mathrm{H}_{28.20}\right)$ and RME $\left(\mathrm{C}_{19.06} \mathrm{H}_{35.26} \mathrm{O}_{2}\right)$. Figure 1 shows the reformer product gas compositions obtained by reforming of B50 at $290{ }^{\circ} \mathrm{C}$ reactor inlet temperature for the test points described in Table 4. Higher hydrogen production was achieved when water was added to the reformer [29]. The reactor inlet temperature temperature of $290{ }^{\circ} \mathrm{C}$ was the same as the engine exhaust gas temperature measured when the engine operated at $1500 \mathrm{rpm}, 4.5$ bar IMEP. The hydrogen content of the reformed gas was up to $21 \%$ while the CO was in the range of $5-7 \%$. The authors have shown previously that the use of appropriate catalysts and reactor design can reduce the produced $\mathrm{CO}$ by reaction with water (WGSR) to produce additional $\mathrm{H}_{2}[29,30]$. With full $\mathrm{CO}$ conversion by the WGSR, up to $25 \%$ hydrogen would be achieved. Details regarding the reforming reactions have been presented in recent publications $[30,35]$.

As has been reported already by many researchers including the authors, the combustion of oxygenated fuels like biodiesel in a CI engine results in a significant reduction of incomplete combustion carbon related emissions (i.e. smoke) while the $\mathrm{NO}_{\mathrm{x}}$ emissions may be increased $[1,12,26]$. For the engine operating conditions described here, the $\mathrm{NO}_{\mathrm{x}}$ emissions with $\mathrm{B} 50$ were 
higher than those obtained with diesel by $25 \%$ and $50 \%$ at 4.5 bar IMEP and 6.1 bar IMEP, respectively. The corresponding decreases of smoke were $70 \%$ and $55 \%$, respectively.

Figure 2 shows the effects of REGR on smoke and $\mathrm{NO}_{\mathrm{x}}$ emissions with standard and retarded injection timing (by $3 \mathrm{CAD}$ ). For comparison the effects of EGR are also shown.

In the case of the low load engine condition (4.5 bar IMEP), the use of REGR with standard injection timing did not affect the smoke emissions (they remained at similar levels as without REGR). There was a reduction of $\mathrm{NO}_{\mathrm{x}}$ but not as significant as with standard EGR. In the case of the second engine operating condition at 6.1 bar IMEP, the effect of REGR on $\mathrm{NO}_{\mathrm{x}}$ emissions was worse as REGR did not result in $\mathrm{NO}_{\mathrm{x}}$ reduction. However, the smoke emissions were much lower with REGR compared to EGR (by up to two Bosch number units).

When REGR was added to the engine, the B50 flow had to be reduced as additional fuel $\left(\mathrm{H}_{2}\right)$ was entering the engine. In this case, there was more pronounced premixed combustion while the diffusion phase was reduced. With the reduction of the diffusion combustion phase and the replacement of hydrocarbon fuel by hydrogen, a simultaneous reduction of smoke and $\mathrm{NO}_{\mathrm{x}}$ emissions would have been expected. However, smoke was already low due to the combustion of the biodiesel while the more pronounced homogeneous combustion resulted in higher $\mathrm{NO}_{\mathrm{x}}$ compared to operation with standard EGR. The use of REGR with retarded injection timing (by $3 \mathrm{CAD}$ ) reduced the $\mathrm{NO}_{\mathrm{x}}$ emissions to levels comparable to those achieved with the use of EGR while smoke could be maintained at much lower levels compared to those with EGR.

As shown in Figure 3, the cylinder peak pressure was up to 5 bar higher when REGR was added compared to the engine operation without REGR. This was due to the advanced combustion and increased amount of fuel taking part in the initial uncontrolled premixed combustion phase (uncontrolled heat release phase). It is well known that mixing hydrogen with other fuels extends the flammability limits of the mixture and accelerates the relatively slow 
reaction rates of typical hydrocarbon fuels. When the faster premixed combustion of the hydrogen-B50 mixture occurs at the right timing (CAD), it can result in the reduction of $\mathrm{NO}_{\mathrm{x}}$, smoke and engine thermal losses [19]. The diluent $\mathrm{CO}_{2}$ contained in the REGR can result in further $\mathrm{NO}_{\mathrm{x}}$ reduction. Furthermore, apart from the reduction of $\mathrm{NO}_{\mathrm{x}}$ and not significantly affected smoke (Figure 3), a reduction of fuel consumption by $3 \%$ was achieved with the use of $20 \%$ REGR compared to operation without REGR, as shown in Figure 4. In the case of the higher load operation of 6.1 bar IMEP with $20 \%$ REGR, the increased cylinder pressure and hence higher cylinder temperatures compared to 0\% REGR operation resulted in shorter and advanced combustion. This is evident from the rates of heat release (ROHR) shown in Figure 5. Retarding the diesel fuel injection timing with $20 \%$ REGR did not affect significantly the ROHR pattern compared to standard injection timing, but the combustion was significantly retarded. It is clear that optimization of the engine - REGR system is required in order for the benefits of the hydrogen- rich gas to be realised.

Similar results have been achieved with dual fuelled combustion engines where part of the diesel fuel was replaced with high octane fuel (i.e. hydrogen, methane, methanol, gasoline) premixed at the inlet manifold, e.g. [27]. This in conjunction with late diesel injection (near TDC) resulting in more premixed combustion. The main objective of these techniques, similarly to the REGR addition, is to reduce or eliminate the diffusion combustion phase by the spontaneous ignition of the homogeneous mixture preferably at TDC (Figure 5) so that improvements in emissions and fuel consumption by reducing the compression work can be achieved.

In the case of the higher load operation of 6.1 bar IMEP, the increased cylinder pressure and hence higher cylinder temperature compared to 4.1 bar IMEP resulted in a shorter ignition delay. The air-fuel mixture, which probably had become homogeneous by the time of ignition 
was combusted earlier in the compression stroke. The advanced combustion resulted in higher $\mathrm{NO}_{\mathrm{x}}$ emissions with REGR compared to EGR. This was overcome by retarding the injection timing (Figure 2). The maximum cylinder pressure rise rate (associated with engine knock and combustion noise) was 3.48 bar/CAD for the engine operation without EGR/REGR and increased to 6.78 bar/CAD with 20\% REGR. With 20\% REGR and retarded injection timing the maximum pressure rise rate was $5.03 \mathrm{bar} / \mathrm{CAD}$.

\subsection{Bioethanol reforming and combustion results}

As the HCCI engine was run at stoichiometric air fuel ratio with residual gas trapping, the main exhaust gas parameter that changed with load was the temperature. The exhaust gas composition varied minimally and typically it was: $\mathrm{CO} 0.5 \%$ vol., $\mathrm{CO}_{2} 14 \%$ vol., $\mathrm{O}_{2}$ 0.8\%vol., HC $220 \mathrm{ppm}$ and $\mathrm{NO}_{\mathrm{x}}$ only $1 \mathrm{ppm}$. The reactant ratios from some representative ethanol exhaust gas reforming tests using different exhaust, air and fuel flow rates are shown in Table 5. Figure 6 shows the corresponding reactor product gas compositions (dry basis \%vol.) obtained by reforming of bioethanol at $370{ }^{\circ} \mathrm{C}$ reactor inlet temperature. This temperature was similar to the engine exhaust gas temperature measured when the engine operated at $1500 \mathrm{rpm}, 2.7 \mathrm{bar}$ IMEP. The low exhaust gas temperature is not favourable for the SRR to occur and provide a satisfactory amount of hydrogen-rich gas. In this case, air was added to the reformer to increase the hydrogen production (this was not necessary in the case of B50 due to the high exhaust gas oxygen content of the diesel engine lean combustion). The addition of oxygen (or atmospheric air) can effectively increase the temperature in the reactor due to oxidation of part of the fuel. The endothermic SRR can then take place more efficiently. However, this results in the reduction of the reforming process efficiency and hence increases the system (engine-reactor) fuel consumption. The $\mathrm{CH}_{4}$ produced in the reactor by bioethanol decomposition at low reactor 
temperatures can also be reformed by steam reforming with high conversion efficiency at temperatures higher than $700{ }^{\circ} \mathrm{C}[36]$. Depending on the engine exhaust gas temperature, an appropriate selection of the reactant rates (fuel, exhaust gas and air) is necessary so that under certain conditions autothermal or even endothermic (overall) conditions can be achieved.

The maximum hydrogen produced in the reactor was about $15 \%$ (Figure 6). The produced $\mathrm{CO}$ and $\mathrm{CH}_{4}$ are fuels that can be also combusted in the engine. As in the case of B50 reforming, additional $\mathrm{H}_{2}$ could be potentially produced by reaction of $\mathrm{CO}$ with water (WGSR) [29]. With full CO conversion, up to $20 \%$ hydrogen would be achieved.

Figure 7 shows that the engine tolerance to EGR during HCCI operation with bioethanol and residual gas trapping could be extended using REGR. The tolerances to EGR and REGR were determined by the maximum EGR/REGR levels that could be used without resulting in unacceptable combustion stability. The latter was considered unsatisfactory when the coefficient of variation of IMEP exceeded 5\%. It appears that hydrogen addition allowed increased amounts of EGR to be tolerated by the engine before large cyclic variations were encountered. It can also be noted that with increasing engine load, both EGR and REGR tolerances decreased.

Figure 8 shows that with increasing load without EGR, the $5 \%$ burn point, which is closely related to the start of ignition, retarded from 4 CAD BTDC to TDC (combustion TDC, indicated as $0 \mathrm{CAD}$ ). This is due to the nature of HCCI with residual gas trapping, where with increasing load, less residuals are trapped, resulting in lower available in-cylinder thermal energy for the next cycle. Both EGR and REGR showed retarded combustion phasing compared to HCCI without EGR/REGR. As the air fuel ratio was the same in all cases, this was due to the displacement of hot trapped residuals in-cylinder by cooler EGR that resulted in delayed combustion phasing. 
REGR allowed a larger retardation of the combustion phasing compared to both HCCI without EGR and HCCI with EGR. The maximum retardation allowed was 1 CAD after TDC, while HCCI without EGR was not stable when the $5 \%$ burn point was after TDC. It appears that hydrogen addition assisted in the combustion process even if the start of ignition was retarded.

Retarding the start of ignition, while maintaining cyclic stability, allowed lower maximum pressure rise rates, as shown in Figure 9a. The maximum rates of pressure rise for HCCI with REGR showed a reduction of 0-1.5 bar/CAD compared to HCCI without EGR. With external EGR, the reduction was much smaller due to the lower engine tolerance to EGR. With lower maximum rates of pressure, the combustion noise is reduced. Noise level measurements were not obtained in the present study but using the vibrational velocity as a guide, it appears that REGR resulted in noise reduction. Figure $8 \mathrm{~b}$ shows that there was up to $25 \%$ reduction of the vibrational velocity with REGR compared to the operation without EGR. This indicates that by using REGR there might be lower requirements for sound dampening for HCCI engines.

As noted before, as the engine load increases both REGR and EGR tolerances decrease due to the displacement of hot trapped residuals in the cylinder. One possible method to maximise the benefits of REGR would be to heat the intake air slightly, which would allow a greater amount of REGR to be inducted. A way of doing so could be through forced induction of hot REGR, which would increase the mass of REGR in the cylinder, thus resulting in lower maximum rates of pressure rise. The hydrogen content of REGR would allow for lower intake temperature requirements during such a process as it has been shown previously that hydrogen addition can lower thermal requirements for HCCI [37]. 


\section{Conclusions}

The application of exhaust gas fuel reforming in engines fuelled with biofuels has been studied by adding simulated reformed gas in a diesel engine fuelled with a mixture of $50 \%$ ULSD and 50\% RME (B50) and in an HCCI engine fuelled with bioethanol. The main findings of the study can be summarised as follows:

- A reformed fuel with up to $21 \%$ and $15 \%$ hydrogen content was produced by exhaust gas fuel reforming of B50 and bioethanol, respectively. Potentially, with full CO conversion by the water gas shift reaction, up to $25 \%$ and $20 \%$ hydrogen can be achieved by reforming of B50 and bioethanol, respectively.

- REGR addition to the biodiesel fuelled engine resulted in lower smoke emissions compared to engine operation with standard EGR. $\mathrm{NO}_{\mathrm{x}}$ levels could be reduced without significant smoke increase when the injection timing was retarded.

- With REGR addition, the biodiesel fuel consumption was lower by $3 \%$ compared to operation without REGR.

- The bioethanol fuelled HCCI engine showed higher tolerance to REGR than EGR due to the hydrogen content of REGR.

- The higher levels of REGR tolerated by the HCCI engine compared to EGR allowed larger reductions of the maximum rates of pressure rise with REGR than EGR due to retarded combustion phasing.

\section{REFERENCES}

[1] Graboski MS, Ross JD, McCormick RL. Transient emissions from No. 2 diesel and biodiesel blends in a DDC Series 60 engine. SAE Paper No. 961166, 1996. 
[2] Graboski MS, McCormick LR. Combustion of fat vegetable oil derived fuels in diesel engines. Prog. Energy Sci. 1998;24:125-164.

[3] Peterson CL, Reece DL. Emissions testing with blends of esters of rapeseed oil fuel with and without a catalytic converter. SAE Paper No 961114, 1996.

[4] Mueller CJ, Picket LM, Siebers DL, Pitz WJ, Westbrook CK, Martin GC. Effects of oxygenates on soot processes in DI diesel engines: experimental and numerical simulations. SAE Paper No. 2003-01-1791, 2003.

[5] McCormick RL, Williams A, Ireland J, Brimhall M, Hayes RR. Effects of biodiesel blends on vehicle emissions. National Renewable Energy Laboratory-NREL/MP-540-40544, Located: www.nrel.gov/vehiclesandfuels/npbf/pdfs/40554.pdf, October 2006.

[6] Senatore A, Cardone M, Rocco V, Prati MV. A comparative analysis of combustion process in a D.I. diesel engine fueled with biodiesel and diesel fuel. SAE Paper No. 200001-0691, 2000.

[7] Szybist JP, Boehman AL. Behavior of a diesel injection system with biodiesel fuel. SAE paper No. 2003-01-1039, 2003.

[8] Boehman AL, Morris D, Szybist J, Esen E. The impact of the bulk modulus of diesel fuels on fuel injection timing. Energy \& Fuels 2004;18:1877-1882.

[9] Scholl KW, Sorenson SC. Combustion of soybean oil methyl ester in a direct injection diesel engine. SAE Paper No. 930934, 1993.

[10] Rakopoulos CD, Antonopoulos KA, Rakopoulos DC, Hountalas DT, Giakoumis EG. Comparative performance and emissions study of a direct injection diesel engine using blends of diesel fuel with vegetable oils or bio-diesels of various origins. Energy Conversion and Management 2006;47:3272-87. 
[11] Demirbas A. Progress and recent trends in bio-fuels. Prog Energy Combust Sci 2007;37:118

[12] Cheng AS, Upatnieks A, Mueller CJ. Investigation of the impact of biodiesel fuelling on $\mathrm{NO}_{\mathrm{x}}$ emissions using an optical direct injection diesel engine. Int. Journal of Engine Research 2006;7:297-318.

[13] Zhang Y, Boehman AL. Impact of Biodiesel on NOx Emissions in a Common Rail Direct Injection Diesel Engine. Energy \& Fuels 2007;21:2003-12.

[14] Wang M, Saricks C, Santini D. Effects of fuel ethanol use on fuel-cycle energy and greenhouse gas emissions. Center for Transportation Research, Energy Systems Division, Argonne National Laboratory (1999), Contract No. W-31-109-ENG-38.

[15] Bata RM, Elond AC, Rice RW. Emissions from IC engines fueled with alcohol-gasoline blends: a literature review. ASME Transactions 1989;111:421-431.

[16] Taljaard HC, Jordaan CFP, Botha JJ. The effect of oxygen content in different oxygenategasoline blends on performance and emissions in a single cylinder, spark-ignition engine. SAE Paper No. 910379, 1991.

[17] Najt PM, Foster DE. Compression-ignited homogeneous charge combustion. SAE Paper No. 830264, 1983.

[18] Thring RH. Homogeneous charge compression ignition (HCCI) engines. SAE Paper No. 892068, 1989.

[19] Gray AW, III, Ryan WT. Homogeneous charge compression ignition (HCCI) of diesel fuel. SAE Paper No. 971676, 1997.

[20] Christensen M., Johansson B., Einewall P. Homogeneous charge compression ignition (HCCI) using iso-octane, ethanol and natural gas - a comparison with spark ignition operation. SAE Paper No. 972824, 1997. 
[21] Christensen M., Hultqvist A., Johansson B. Demonstrating the multi fuel capability of a homogenous charge compression ignition engine with variable compression ratio. SAE Paper No. 1999-01-3679, 1999.

[22] Yap D., Megaritis A. Applying forced induction to bioethanol HCCI operation with residual gas trapping. Energy \& Fuels 2005;19:1812-21.

[23] Yap D., Megaritis A., Wyszynski ML. An experimental study of bioethanol HCCI. Combustion Science and Technology 2005;177:2039-68.

[24] Lavy J, Dabadie JC, Angelberger C, Wiland J, Juretzka A, Schaflein J, Ma T, Lendresse Y, Satre A, Schulz C, Kramer H, Zhao H, Damiano L. Innovative ultra-low $\mathrm{NO}_{\mathrm{x}}$ controlled auto-ignition combustion process for gasoline engines: the 4-Space project. SAE Paper No. 2000-01-1837, 2000

[25] Oakley A, Zhao H, Ladommatos N. Experimental studies on controlled auto-ignition (CAI) combustion of gasoline in a 4-stroke engine. SAE Paper No. 2001-01-1030, 2001.

[26] Tsolakis A, Megaritis A, Wyszynski ML. Application of exhaust gas fuel reforming in compression ignition engines fueled by diesel and biodiesel fuel mixtures. Energy \& Fuels 2003;17:1464-1473.

[27] Kumar MS, Ramesh A, Nagalingam B. Use of hydrogen to enhance the performance of a vegetable oil fuelled compression ignition engine. Int J Hydrogen Energy 2003;28:11431154.

[28] Apostolescu N, Chiriac R. A study of combustion of hydrogen-enriched gasoline in a spark ignition engine. SAE Paper No. 960603, 1996.

[29] Tsolakis A, Megaritis A. Catalytic exhaust gas fuel reforming for diesel engines - effects of water addition on hydrogen production and fuel conversion efficiency. Int J Hydrogen Energy 2004;29:1409-19. 
[30] Tsolakis A, Megaritis A, Golunski SE. Reaction profiles during exhaust assisted reforming of diesel engine fuels. Energy \& Fuels 2005;19:744-52.

[31] Tsolakis A, Megaritis A, Wyszynski ML, Theinnoi K. Engine performance and emissions of a diesel engine operating on diesel-RME (rapeseed methyl ester) blends with EGR (exhaust gas recirculation). Energy, 2007, in press.

[32] Tsolakis A, Megaritis A. Exhaust gas assisted reforming of rapeseed methyl ester for reduced exhaust emissions of CI engines. Biomass \& Bioenergy 2004;27:493-505.

[33] Megaritis A, Yap D., Wyszynski ML. Effect of water blending on bioethanol HCCI combustion with forced induction and residual gas trapping. Energy, 2007, in press.

[34] Tsolakis A, Megaritis A, Wyszynski ML. Low temperature exhaust gas fuel reforming of diesel fuel. Fuel 2004;83:1837-45.

[35] Tsolakis A., Golunski S. E. Sensitivity of Process Efficiency to Reaction Routes in Exhaust-Gas Reforming of Diesel Fuel, Chemical Engineering Journal 2006;117: 131-36

[36] Breen JP, Burch R, Coleman HM. Metal-catalysed steam reforming of ethanol in the production of hydrogen for fuel cell applications. Appl. Catal. B: Env. 2002;39:65-74.

[37] Yap D., Megaritis A., Peucheret S., Wyszynski M.L., Xu H. Effect of hydrogen addition on natural gas HCCl combustion. SAE Paper No. 2004-01-1972, 2004. 


\section{FIGURE CAPTIONS}

Figure 1. Reactor product gas composition obtained with B50 exhaust gas fuel reforming.

Figure 2. Effects of REGR and EGR on the diesel engine $\mathrm{NO}_{\mathrm{x}}$ and smoke emissions.

Figure 3. Effects of REGR and EGR on the diesel engine cylinder peak pressure.

Figure 4. Effect of EGR and REGR on the diesel engine fuel consumption.

Figure 5. Cylinder pressure and ROHR for the engine operation at $1500 \mathrm{rpm}, 6.1$. bar IMEP with 0\% REGR, 20\% REGR and 20\% REGR with retarded injection timing.

Figure 6. Reactor product gas composition obtained with bioethanol exhaust gas fuel reforming.

Figure 7. Comparison of HCCI engine tolerance to REGR and EGR (the lines indicate the general trend of EGR/REGR with IMEP).

Figure 8. Effects of EGR and REGR on the $5 \%$ burn point at different HCCI engine loads (0 CAD corresponds to combustion TDC).

Figure 9. Effects of REGR and EGR on the HCCI engine maximum cylinder pressure rise rate and vibrational velocity. 
Table 1. Fuel properties.

\begin{tabular}{|c|c|c|c|c|}
\hline Fuel Analysis & Method & $\begin{array}{c}\text { Ultra Low } \\
\text { Sulphur Diesel } \\
\text { (ULSD) }\end{array}$ & $\begin{array}{c}\text { Rapeseed } \\
\text { Methyl Ester } \\
\text { (RME) }\end{array}$ & Ethanol \\
\hline Cetane Number & ASTM D613 & 53.9 & 54.7 & 8 \\
\hline Density at $15^{\circ} \mathrm{C}\left(\mathrm{kg} \mathrm{m}^{-3}\right)$ & ASTM D4052 & 827.1 & 883.7 & 785 \\
\hline Viscosity at $40{ }^{\circ} \mathrm{C}(\mathrm{cSt})$ & ASTM D445 & 2.467 & 4.478 & \\
\hline $50 \%$ distillation $\left({ }^{\circ} \mathrm{C}\right)$ & ASTM D86 & 264 & 335 & \\
\hline $90 \%$ distillation $\left({ }^{\circ} \mathrm{C}\right)$ & ASTM D86 & 329 & 342 & \\
\hline $\mathrm{LCV}\left(\mathrm{MJ} \mathrm{kg}^{-1}\right)$ & & 42.7 & 39 & 27.7 \\
\hline Sulphur $\left(\mathrm{mg} \mathrm{kg}^{-1}\right)$ & ASTM D2622 & 46 & 5 & \\
\hline \multicolumn{5}{|l|}{ AROMATICS } \\
\hline MONO (\% wt) & & 21.0 & $<0.1$ & \\
\hline DI (\% wt) & & 3.1 & $<0.1$ & \\
\hline TRI $(\%$ wt) & & 0.3 & 32.1 & \\
\hline TOTAL (\% wt) & & 24.4 & 32.1 & \\
\hline Molecular Weight & & 209 & 296 & 46 \\
\hline $\mathrm{C}(\% \mathrm{wt})$ & & 86.5 & 77.2 & 52.2 \\
\hline $\mathrm{H}(\% \mathrm{wt})$ & & 13.5 & 12 & 13 \\
\hline $\mathrm{O}(\% \mathrm{wt})$ & & - & 10.8 & 34.8 \\
\hline
\end{tabular}


Table 2. Accuracy of measurements and uncertainly of computed results.

\begin{tabular}{ll}
\hline Measurements & Accuracy \\
\hline $\mathrm{NO}_{\mathrm{x}}$ & $1 \mathrm{ppm}$ (Digas 4000) and \\
& $5 \mathrm{ppm}$ (Chemiluminescence) \\
$\mathrm{CO}$ & $0.01 \%$ \\
$\mathrm{CO}_{2}$ & $0.01 \%$ \\
$\mathrm{HC}$ & $1 \mathrm{ppm}$ \\
$\mathrm{Smoke}(\mathrm{BSN})$ & 0.2 \\
Time & $0.5 \%$ \\
Speed & $5 \mathrm{rpm}$ \\
Torque & $0.2 \mathrm{Nm}$ \\
& \\
Computed Results & Uncertainty \\
\hline Fuel volumetric rate & $1 \%$ \\
Power & $1 \%$ \\
Brake specific fuel consumption & $1.5 \%$ \\
Efficiency & $1.5 \%$ \\
\hline
\end{tabular}


Table 3. Diesel engine exhaust gas composition (wet basis) with B50 fuelling.

\begin{tabular}{cccccc}
\hline $\begin{array}{c}\text { IMEP } \\
(\mathbf{b a r})\end{array}$ & $\begin{array}{c}\mathbf{C O} \\
(\boldsymbol{\%})\end{array}$ & $\begin{array}{c}\mathbf{O}_{\mathbf{2}} \\
(\boldsymbol{\%})\end{array}$ & $\begin{array}{c}\mathbf{C O}_{\mathbf{2}} \\
(\boldsymbol{\%})\end{array}$ & $\begin{array}{c}\mathbf{H}_{\mathbf{2}} \mathbf{O} \\
(\boldsymbol{\%})\end{array}$ & $\boldsymbol{\lambda}$ \\
\hline $\mathbf{4 . 5}$ & 0.01 & 12.60 & 4.76 & 5.02 & 2.60 \\
$\mathbf{6 . 1}$ & 0.01 & 10.80 & 6.30 & 6.40 & 2.14 \\
\hline
\end{tabular}


Table 4. B50 reforming conditions.

\begin{tabular}{|c|c|c|c|c|c|c|c|}
\hline $\begin{array}{l}\text { Test } \\
\text { Points }\end{array}$ & $\begin{array}{c}\text { IMEP } \\
\text { (bar) }\end{array}$ & $\begin{array}{c}\text { Exhaust } \\
\text { (1/min) }\end{array}$ & $\begin{array}{c}\text { Fuel } \\
(\mathrm{ml} / \mathrm{h})\end{array}$ & $\begin{array}{c}\mathrm{H}_{2} \mathrm{O} \\
(\mathrm{ml} / \mathrm{h})\end{array}$ & $\mathrm{O} / \mathrm{C}$ & $\mathrm{O}_{2} / \mathrm{C}$ & $\mathrm{H}_{2} \mathrm{O} / \mathrm{C}$ \\
\hline 1 & & & 34 & 0 & 2.3 & & 2.26 \\
\hline 2 & 4.5 & 8 & 34 & 30 & 3.1 & 0.98 & 3.09 \\
\hline 3 & & & 40 & 0 & 2.2 & & 2.21 \\
\hline 4 & & & 40 & 30 & 2.9 & & 2.92 \\
\hline 5 & & & 34 & 0 & 2.1 & & 2.09 \\
\hline 6 & 6.1 & 8 & 34 & 30 & 2.9 & 0.83 & 2.92 \\
\hline 7 & & & 40 & 0 & 2.0 & & 2.03 \\
\hline 8 & & & 40 & 30 & 2.7 & & 2.74 \\
\hline
\end{tabular}


Table 5. Bioethanol reforming conditions.

\begin{tabular}{ccccccc}
\hline $\begin{array}{c}\text { Test } \\
\text { Points }\end{array}$ & $\begin{array}{c}\text { Air } \\
\text { l/min }\end{array}$ & $\begin{array}{c}\text { Exhaust } \\
\text { l/min }\end{array}$ & $\begin{array}{c}\text { Fuel } \\
\mathbf{m l} / \mathbf{h}\end{array}$ & $\mathbf{O} / \mathbf{C}$ & $\mathbf{O}_{2} / \mathbf{C}$ & $\mathbf{H}_{\mathbf{2}} \mathbf{O} / \mathbf{C}$ \\
\hline $\mathbf{1}$ & 3.0 & 9 & 50 & 3.54 & 0.90 & 1.74 \\
$\mathbf{2}$ & 3.0 & 9 & 55 & 3.23 & 0.82 & 1.59 \\
$\mathbf{3}$ & 3.0 & 9 & 60 & 2.95 & 0.75 & 1.54 \\
$\mathbf{4}$ & 2.0 & 10 & 50 & 3.10 & 0.60 & 1.90 \\
$\mathbf{5}$ & 2.5 & 10 & 50 & 3.40 & 0.75 & 1.90 \\
$\mathbf{6}$ & 4.0 & 8 & 60 & 3.24 & 0.99 & 1.26 \\
$\mathbf{7}$ & 4.0 & 8 & 65 & 3.01 & 0.92 & 1.17 \\
$\mathbf{8}$ & 4.0 & 8 & 70 & 2.79 & 0.85 & 1.09 \\
\hline
\end{tabular}




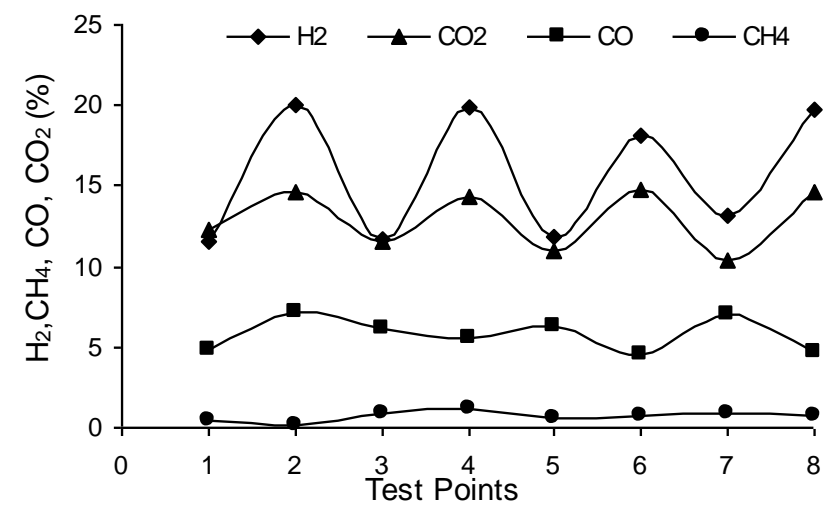

Figure 1. 

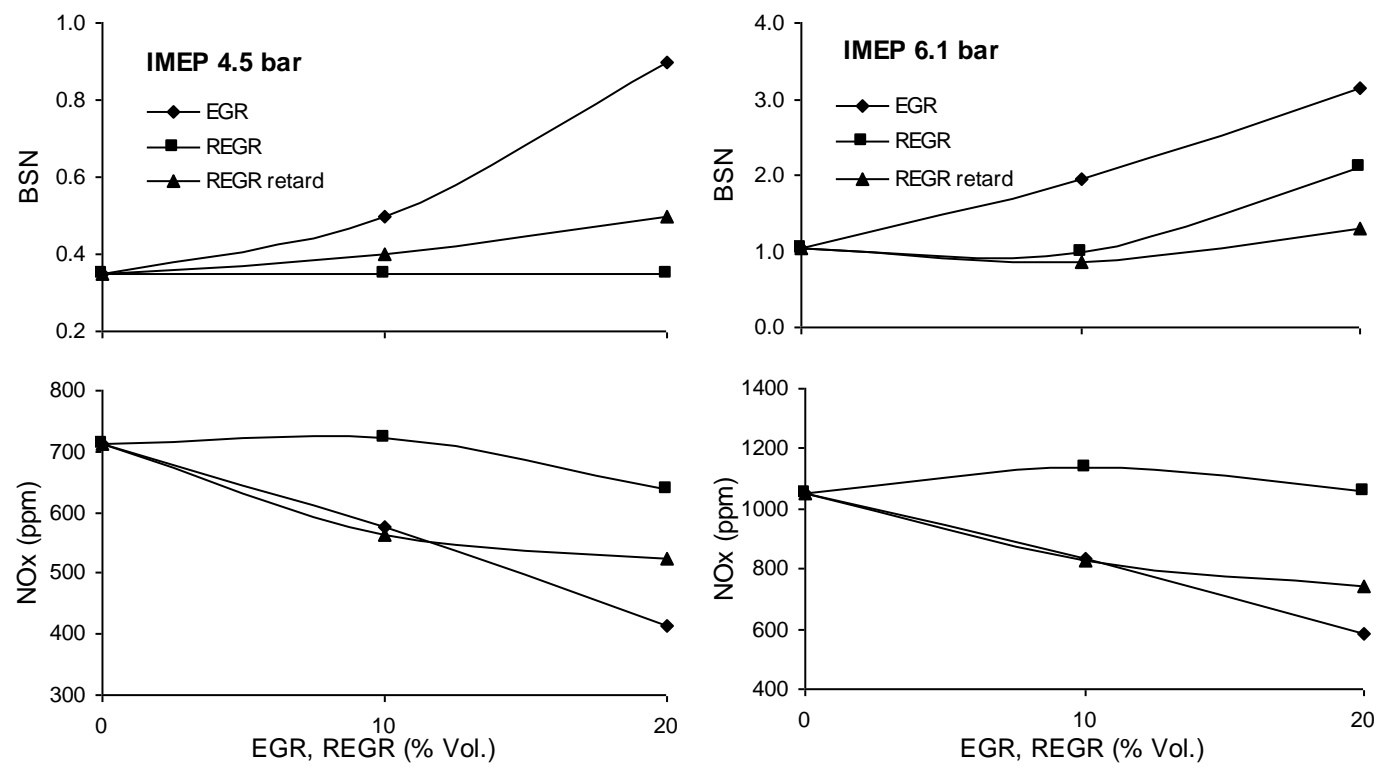

Figure 2. 

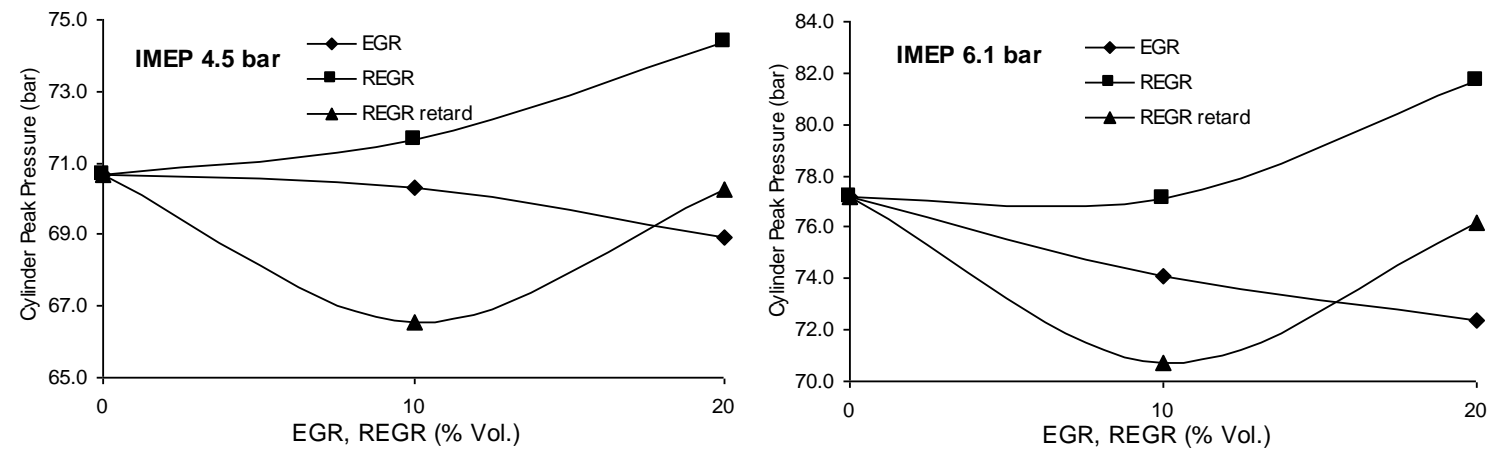

Figure 3. 

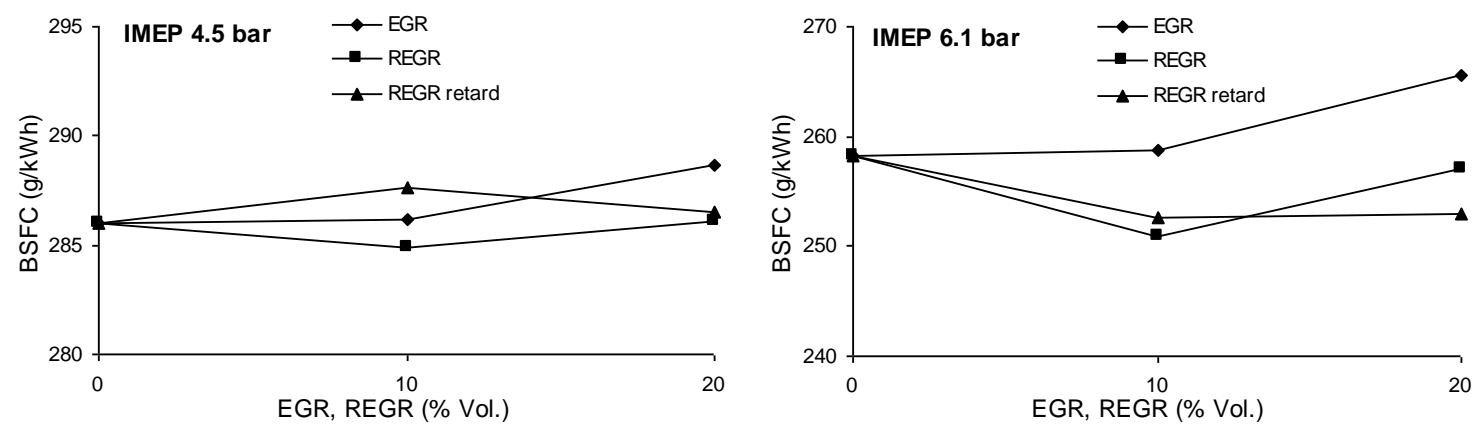

Figure 4. 


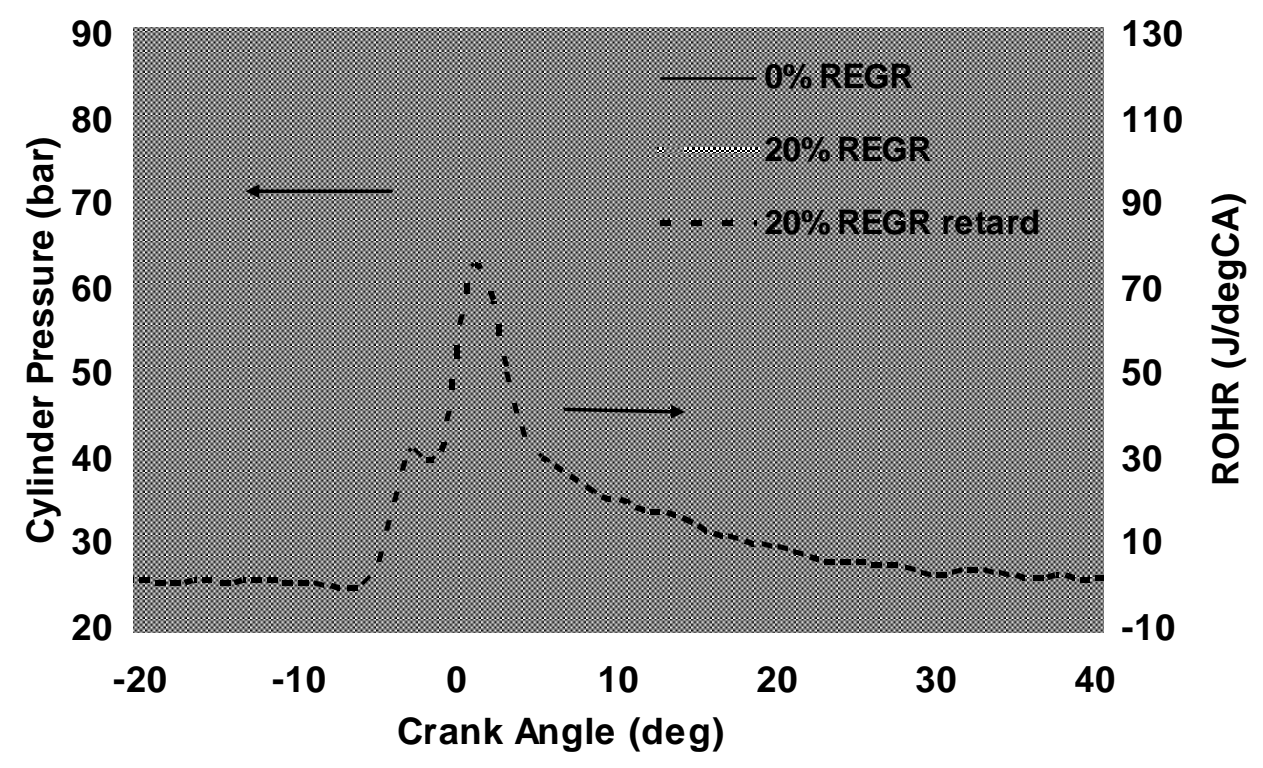

Figure 5. 


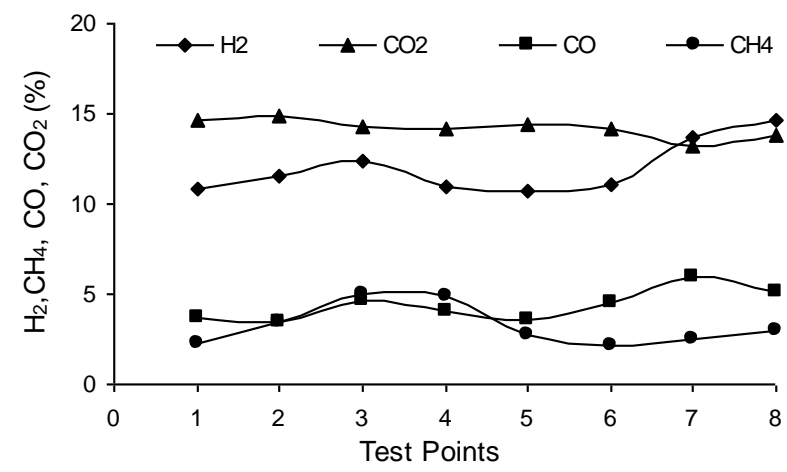

Figure 6. 


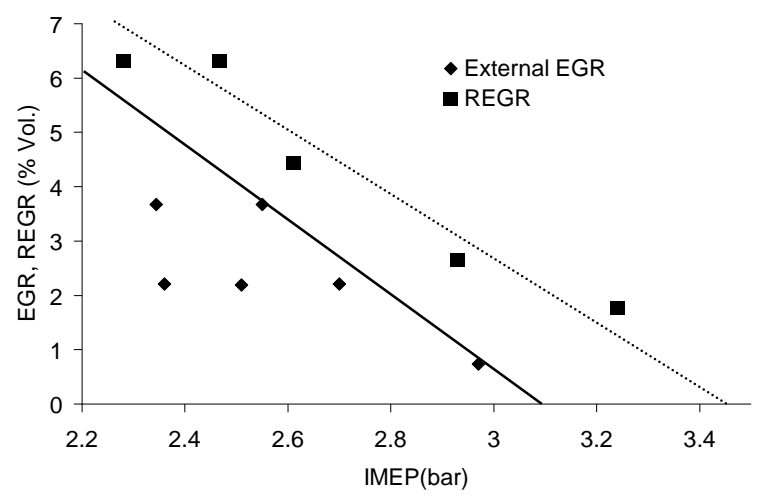

Figure 7. 


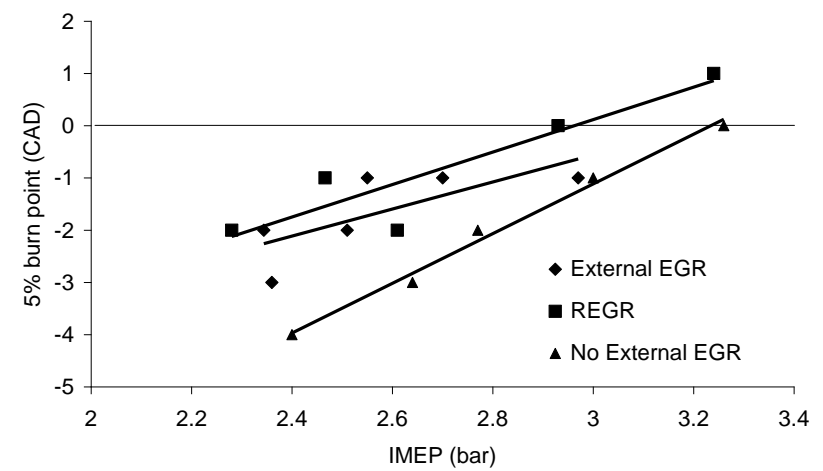

Figure 8. 

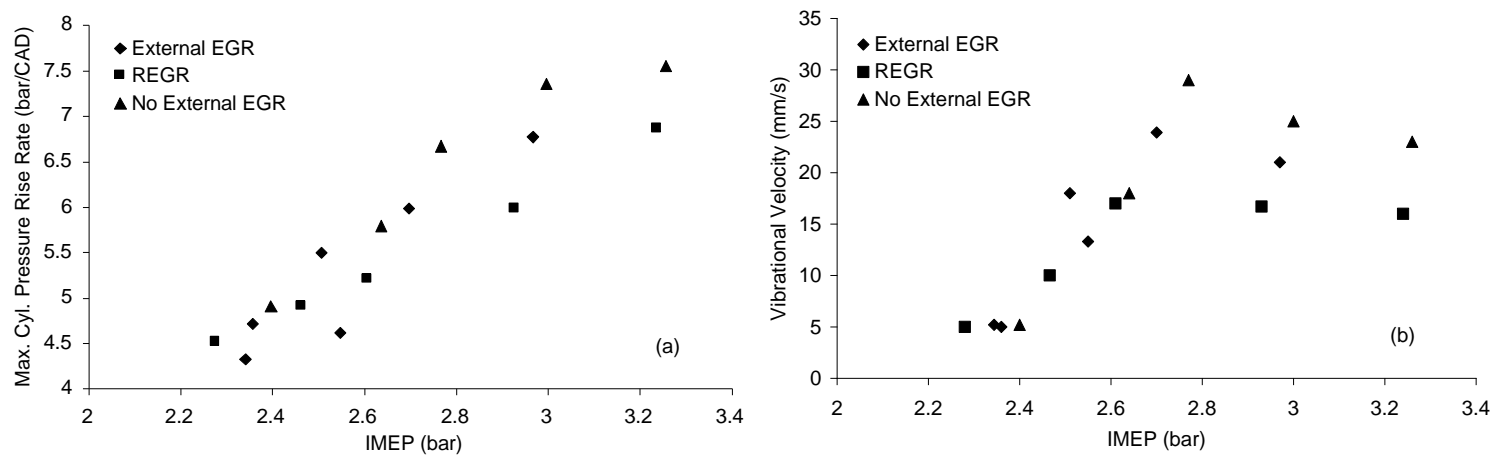

Figure 9. 